\title{
THE EFFECT OF CRITICAL THINKING ON STUDENTS' ACCOUNTING COMPETENCY IN VOCATIONAL HIGH SCHOOL
}

\author{
Risa Alkurnia \\ Universitas Sebelas Maret \\ Susilaningsih \\ Universitas Sebelas Maret \\ Sudiyanto \\ Universitas Sebelas Maret
}

\begin{abstract}
The purpose of this study was to analyze the differences in the effect of critical thinking skills on students' learning competency in accounting subjects at vocational high school in Surakarta. The indicators of critical thinking ability used in this study referred to the theory developed by Ennis, while the accounting competency indicators used referred to Bloom's taxonomy. This research was experimental quantitative research. The population in this study were all students of grade $X$ accounting at SMK 1 Surakarta totaling 96 students. The sample of this study was class X AC (Accounting) 2 as the experimental class and X AC 3 as the control class. The sampling technique used in this study was Cluster Random sampling. The data analysis technique used in the study was Analysis of Variance (ANOVA), with pre-requisite tests that had to be done before, namely normality and homogeneity tests. This study concluded that there are differences in the influence of critical thinking skills on students' competency in accounting learning.
\end{abstract}

Keywords: critical thinking, learning competency, accounting learning, vocational high school

Permalink: http://dx.doi.org/10.21831/jpv.v9i3.27664

Contact Risa Alkurnia

risalprada@gmail.com

Master Program of Economic Education, Universitas

Sebelas Maret

Jl. Ir. Sutami No. 36 A, Surakarta (Solo) 57126,

Indonesia 


\section{INTRODUCTION}

Learning is an activity carried out between students and teachers that aims to develop student competency based on educational goals. The development of student competency is essential as a provision in facing future life challenges. To develop the competence of the next generation, an educational institution, such as school, is needed. One school institution that can help the realization of educational goals is the Vocational High School (VHS).

Vocational students have different needs from senior high school students in the learning curriculum. The vocational school's curriculum has more practice than theory, while the senior high school curriculum has more theory than practice. After their graduation, VHS students are ready to work. They are independent because, in addition to studying at school, VHS students also do Industrial Work Practices (Internship) while high school graduates are not ready to work and are encouraged to continue to further education. It is in accordance with the Regulation of the Minister of Education and Culture No. 70 of 2013 concerning vocational curriculum structures that prioritize preparing students to enter the working world and develop professional attitudes. To adjust to the working world, vocational schools have several choices of fields of expertise. One of them is the area of business and expertise. The areas of business and management expertise in vocational schools generally consist of Accounting, Marketing, and Office Administration skills programs. Accounting is an accounting expertise program which its material characteristic is normatively based on the applied rules and also contains numbers so that with such characteristics, it opens a strong possibility for students to think critically when facing challenges in the working world.

Several previous studies examined critical thinking. Duron, Limbach, and Waugh (2006) stress that learning should emphasize students' ability to think critically with which it is expected that the students and teachers would obtain a fun and more meaningful learning experience. Students need critical thinking skills to be able to understand problems and find the best solutions, develop skills to deal with problems in complex global soci- eties (Snyder \& Snyder, 2008; Springer \& Borthick, 2004). Another study conducted by McCarthy (2004), who examined the relationship between critical thinking and academic ability, concluded that the level of critical thinking of high achieving students is significantly higher than of low and medium students. It is because there is a relationship between critical thinking and a belief perspective, also between belief perspective with student's academic performance. However, research conducted by Jenkins (1998) shows different results about the specific study of critical thinking in the audit course. In his research, he used the Watson-Glaser Critical Thinking Appraisal (WGCTA) instrument in measuring the level of critical thinking. The research resulted in a declining in critical thinking scores. With this setback, Jenkins suggested that the things needed to be firstly concerned were including the previous semester's GPA, age, and gender.

Critical thinking skills are needed as a support to improve students' learning skills, namely communication skills, assessing and evaluating skills, so as to develop a better understanding of existing problems (Paul \& Elder, 2001; Slavin, 2000; ŽivkoviL, 2016). In addition to improving skills, critical thinking can also make students more active and learn more, practice cooperation skills, respect others' opinions. Activeness occurs when students create a series of interrelated questions and then are able to ask and answer questions (Browne \& Keeley, 2009; Fisher, 2009). Critical thinking is a cognitive process to gain knowledge because it is included in the activity of thinking. Critical thinking is a tool which is used in the process of mastery of concepts because conceptual knowledge is the result of a constructive process. Critical thinking activates the ability to analyze and evaluate evidence, identify questions, make logical conclusions, and also understand the implications of arguments (Ennis, 1993, p. 48; Facione \& Facione, 1994). Students are different and diverse individuals. Some are equipped with high critical thinking skills, and some are still having low critical thinking skills (Facione \& Facione, 1994; Glaser \& Resnick, 2001, p. 137). The difference in terms of the thinking ability is possible to result in the varying levels of students' competency achievement. 
Indicators of critical thinking, according to Ennis (1993), include giving simple explanations, building basic skills, making conclusions, giving further explanations, and also managing strategies. More detailed indicators of critical thinking are explained in Table 1.

Learning theory on critical thinking skills is built on constructivism learning theory, carried by researchers such as Dewey (1910), Vygotsky and Cole (1978), Piaget (1988), and Bruner (1966) who believe that all humans have the ability to build knowledge in their minds through the process of discovery and problem-solving. Constructivism learning theory is a learning theory in educational psychology stating that students must be able to find out and connect complex information by themselves, check new knowledge, and harmonize it with the old ones if they have not been harmonized yet (Slavin, 2000). In the constructivist view, the study is seen as the development of knowledge that comes from the individual itself (Browne \& Keeley, 2009; Chukwuyenum, 2013; Zhou, Huang, \& Tian, 2013). Theory of constructivism by Piaget views cognitive development as a process in which students actively build understanding through experience and interaction. The nature of constructivism is about the concept of learning process not just memorizing but the process of constructing knowledge through experience (Abimanyu, 2008; Sanjaya, 2012).

The aim of learning about constructivism in critical thinking is to gain good potential aspects in humans, such as being independent, having the ability to think and give value to a process and its result, and being responsible for taking a risk in making decisions. Developing all aspects of this potential can be achieved through a continuous learning process. The learning process required is the ability to recall and express experiences, compare similarities and differences, and appreciate an experience (Baharuddin \& Wahyuni, 2007, p. 130; Suprihatiningrum, 2013, p. 22; von Glasersfeld, 2007). The aim of constructivism learning also affects the aspects of skills in communicating opinions, the aim of which is to learn to socialize to create reciprocal relationships with people around and environment (Karfi, 2002; Thobroni \& Mustofa, 2011). Humans build knowledge through interactions with objects, phenomena, experiences, and environment. Preliminary knowledge is needed to instill the correct concepts as a basis. Knowledge is the result of the construction of the human mind. Knowledge is not given by others, such as teachers, but the result of process of developing the thinking carried out by each individual (Budiningsih, 2005; Sutiah, 2003). Knowledge aims to develop the ability to ask questions and find answers on their own, help them develop a complete understanding of concepts, develop their abilities to become independent and critical thinkers. Therefore, it can be seen that the theory of constructivism aims to build students' thinking ability to learn by themselves and discover what is learned through interaction, experience, and understanding which those qualities are then expected to be applied and reflected in their attitudes and skills. The referred attitudes are respecting opinions, as well as being responsible for the risk of decision making. Also, the referred skills are communication skills in asking and answering questions. Thus, they, as humans, can solve complex problems for their survival and progress.

Table 1. Critical Thinking Aspects according to Ennis

\begin{tabular}{|c|c|c|}
\hline No & Ability & Sub-Ability \\
\hline 1. & Giving simple explanations & $\begin{array}{l}\text { Focusing the questions } \\
\text { Analyzing arguments } \\
\text { Asking and answering questions }\end{array}$ \\
\hline 2. & Building basic skills & $\begin{array}{l}\text { Considering reliable or unreliable sources } \\
\text { Observing and considering report }\end{array}$ \\
\hline 3. & Making conclusion & $\begin{array}{l}\text { Deducting and considering deduction result } \\
\text { Inducting and considering induction result } \\
\text { Making and deciding the consideration result }\end{array}$ \\
\hline 4. & Giving further explanations & $\begin{array}{l}\text { Defining terms and considering the definition } \\
\text { Identifying asumptions }\end{array}$ \\
\hline 5. & Setting strategies and tactics & $\begin{array}{l}\text { Determining an action } \\
\text { Interacting with others }\end{array}$ \\
\hline
\end{tabular}

Source: Ennis (1993) 
Critical thinking is an important part of learning to be able to solve problems and find solutions (DePorter, Reardon, \& SingerNourie, 2007). Critical thinking is included in the category of thinking skills. The level of thinking ability consists of four levels: memory, basic thinking, critical power, and creative power (Krulik \& Rudnick, 1999). The lowest level of thinking is a memory which consists of skills which are almost automatic or reflexive. The next level of thinking is basic thinking skills. This concept discusses concepts such as addition, etc., including questions. Critical thinking is a discussion that discusses, connects, and improves all aspects of the discussion or problem - included in gathering, organizing, remembering, and analyzing information. Creative thinking is original and reflective. The result of this thinking skill is something complicated. The activities carried out here try to unite ideas, create new ideas, and determine their effectiveness. Creative thinking about also draws conclusions that can find new final results.

Critical thinking is the ability to think that is needed in all fields of learning, not only science but also in the social field (Errington \& Bubna-Litic, 2015) and humanities (Smith, 2014) such as management and business. In accounting, students are not only expected to be able to "calculate", but also to think critically in solving various accounting problems in different contexts. GAAP to IFRS standards also influences changes from the accounting learning paradigm. Schools must prepare to understand and implement IFRS well. The first step that must be taken is that the direction of previous learning is based on ways of learning that are based on principles that encourage accounting students to make disputes, in which critical thinking plays a key role. Accounting learning that has the characteristics of the material as normative learning that provides numbers and problem-solving requires students to perform critical thinking.

Student competency is an ability that must be possessed by each student. The competencies are in the form of cognitive, affective, and psychomotor abilities (Bloom, 1956). Cognitive ability is the ability to understand a concept and more on the ability to think. Affective ability is the ability of students in the form of attitudes, values, and morals. Psychomotor ability is also an important ability in learning. Psychomotor ability can be seen in students' skills or ability to make something related to the concept of learning objectives. The competencies examined in this study are competencies in preparing financial statements. Financial statements, based on Standar Akuntansi Keuangan (SAK) or Financial Accounting Standard (FAS), according to Institute of Indonesia Chartered Accountants or Ikatan Akuntan Indonesia $(2015$, p. 1) are a structured presentation of the financial position and financial performance of an entity. Complete financial statements usually include an income statement, equity changes statement, financial position statement, cash flows statement and notes to the financial statements. Financial statements are a form of a report that describes the company's financial condition, company's development, and the results of operations of a company in a certain period. Based on the aforementioned description, it can be seen that the competency in preparing financial statements of students is the ability of students to prepare reports, which generally include financial position statements, income statements, equity changes statements, cash flows statements, and notes to financial statements.

Students who learn about accounting need to be able to critical thinking, since critical thinking may support the knowledge aspect, and also the students' skills aspect. This research is aimed at analyzing the effect of students' critical thinking on the students' competency in making financial statements.

\section{RESEARCH METHOD}

This research was a quantitative study with a quasi-experimental method. The study was conducted in two selected groups, which had previously been tested for homogeneity and reliability as pre-requisite tests for hypothesis testing. The hypothesis test used is the $\mathrm{F}$ test. The population of this study was all students of grade $\mathrm{X}$ Accounting SMK 1 Surakarta (96 students in total), which consisted of three Accounting classes, namely Class X AC 1 with 32 students, X AC 2 with 32 students and X AC 3 also with 32 students.

The sampling technique used in this study was Cluster Random sampling. Cluster Random sampling was a sampling technique by randomly targeting non-individual groups. 
The samples of this research were class $\mathrm{X} A \mathrm{C}$ 2 as experiment class and X AC 3 as control class (Sukmadinata, 2009, p. 252).

There were two data collection techniques used in this research, which were through documentation and test instruments. Each is elaborated as follows.

\section{Documentation}

Documentation was looking for data about things or variables in the form of notes, transcripts, books, newspapers, magazines, inscriptions, minutes of meetings, lengths, and agendas (Arikunto, 2009). Documentation is intended to obtain data directly from the research site, including relevant books, regulations, activity reports, photographs, documentary films, and data relevant to research (Riduwan, 2010, p. 105).

This study used documentation method to obtain data, such as the number of students, the name of the teachers, the name of the students, the students' scores, and school facilities. Documentation data were used as a complement in the preparation of this study.

\section{Test Instrument}

The test instruments were questions assessed using the rubric of assessment tests, also arranged based on sub-abilities developed by researchers according to indicators of critical thinking skills. Through this rubric, the researchers could determine whether or not the students met each indicator of critical thinking skills in solving problems contained in the problems. This categorization was based on the average value of the two classes. Students who score the same as the average score or above were categorized into high critical thinking group while students with scores below the average were categorized into low critical thinking group.

The purpose of the instrument was to get information about students' critical thinking skills. Conceptually, critical thinking is one's ability to make judgments with good reasoning. Operationally, the ability to think critically is the ability to think reasonably and logically, which helps in making rational decisions. Based on the conceptual definition, it can be concluded that the ability to think critically can be seen from matters related to making decisions or conclusions and is char- acterized by several indicators as follows: (1) Identifying, (2) Evaluating, (3) Concluding and (4) Clarifying as presented in Table 2.

Table 2. Lattice of Instruments Critical Thinking

\begin{tabular}{lllc}
\hline No. & Indicator & \multicolumn{1}{c}{ Type } & Number \\
\hline 1. & To identify & Multiple choice & $1-6$ \\
2. & Evaluate & Multiple choice & $7-12$ \\
3. & Conclude & Multiple choice & $13-19$ \\
4. & To clarify & Multiple choice & $20-25$ \\
\hline
\end{tabular}

As an instrument to measure students' ability to arrange a financial statement, the test questions must meet the criteria. The instrument must first be tested for validity, reliability, level of difficulty, and distinguishing features.

\section{Questions Validity Test}

Test validity is an integrated evaluative assessment conducted by the assessor regarding the extent to which empirical and theoretical rational evidence supports the accuracy of inference and action based on test scores or other assessments (Budiyono, 2015). The validity test in this study used the biserial correlation coefficient formula to test the validity of the test questions. Test criteria were if the value of $r_{\text {count }}>r_{\text {table }}$ with a significance level of 0.05 , then the tool was valid, and vice versa. If the value of $r_{\text {count }}<r_{\text {table, }}$, then the measuring instrument was invalid. The validity test results in this study showed five invalid questions and 20 valid questions, then the questions that can be used were 20 questions.

\section{Questions Reliability Test}

Test questions are considered reliable if the results of measurements with the instrument test questions are the same if it was carried out at the same person at different times or at different people (same conditions) at the same time or at different times (Budiyono, 2015). This study used the KR-21 formula to test the reliability of test questions. With the categories are the value of 0.00 to 0.20 was very low, 0.21 to 0.40 was low, 0.41 to 0.60 was enough, 0.61 to 0.80 was high, 0.80 to 100 was very high. The result of this reliability test on the questions in this study was 0.895 , with a very high category. 


\section{Level of Questions Difficulties}

The level of difficulty of the item shows the proportion of the number of participants who answer the item correctly to all test participants (Budiyono, 2015). The difficulty level is determined by the formula for the difficulty level index of items. The criterion used is the smaller the index obtained, the more difficult the question is. Conversely, the greater the index obtained, the easier the question is, with the categories: 0.00 to 0.30 is a difficult question, 0.30 to 0.70 is a medium question, $0.70-1.00$ is an easy question. In this study, there are five easy questions, 12 medium questions, and eight difficult questions.

\section{Distinguishing Power of Questions}

The question items have a good distinguishing feature if the high achieving group of students has more correct answers than the low achieving group. The distinguishing feature can be used for distinguishing high and low achieving students. The benchmark used was the total score of a set of items analyzed (Budiyono, 2015). The formula is as follows.

$$
\mathrm{D}=\frac{\mathrm{B}_{\mathrm{a}}}{\mathrm{N}_{\mathrm{a}}}-\frac{\mathrm{B}_{\mathrm{b}}}{\mathrm{N}_{\mathrm{b}}}
$$

The following were the criteria for using the distinguishing power index: 0.00 to 0.20: Ugly/Poor, $D=0.20$ to 0.40: Enough, D $=0.40$ to 0.70 : Good, $\mathrm{D}=0.70$ to 1.00 : very good, $\mathrm{D}=$ negative. The distinguishing feature results were 17 with enough criteria and eight with good criteria.

From the results of the validity test, reliability test, the level of difficulty, and distinguishing feature, there were 20 questions that can be used in this study.

\section{RESULTS AND DISCUSSION}

Based on the test results obtained, the average critical thinking ability of students was more classified as high. Data grouping students' critical thinking skills can be seen in and briefly in Table 3 .

Table 3. Distribution of Critical Thinking Ability

\begin{tabular}{lcccc}
\hline Critical & \multicolumn{2}{c}{ Class AC 2 } & \multicolumn{2}{c}{ Class AC 3 } \\
\cline { 2 - 5 } Thinking & Freq & \% & Freq & \% \\
\hline Low & 8 & $23.5 \%$ & 10 & $29 \%$ \\
High & 26 & $76.5 \%$ & 24 & $71 \%$ \\
Total & 34 & $100 \%$ & 34 & $100 \%$ \\
\hline
\end{tabular}

Table 3 shows the categories of students who are classified as high and low critical thinking in the $\mathrm{AC} 2$ and $\mathrm{AC} 3$ classes. In both classes, the number of students classified as high critical thinking is greater. The frequency distribution is shown in Table 4.

Table 4. Distribution of Critical Thinking Frequency

\begin{tabular}{ccccc}
\hline Interval & \multicolumn{2}{c}{ Class AC 2 } & \multicolumn{2}{c}{ Class AC 3 } \\
\cline { 2 - 5 } Class & Freq & \% & Freq & $\%$ \\
\hline $55-58$ & 6 & $17.6 \%$ & 3 & $8.8 \%$ \\
$59-62$ & 5 & $14.7 \%$ & 3 & $8.8 \%$ \\
$63-66$ & 11 & $32.4 \%$ & 7 & $20.6 \%$ \\
$67-70$ & 7 & $20.6 \%$ & 16 & $47.1 \%$ \\
$71-74$ & 4 & $11.8 \%$ & 4 & $11.8 \%$ \\
$75-78$ & 1 & $2.9 \%$ & 1 & $2.9 \%$ \\
Total & 34 & $100.0 \%$ & 34 & $100.0 \%$ \\
\hline
\end{tabular}

Table 4 explains the frequency distribution of critical thinking skills in AC2 and AC3 classes. Class $\mathrm{AC} 2$ raises the highest frequency is in the 63-66 interval, and in the AC3 class, the highest frequency is in the 67-70 interval. Student competency data is presented in Table 5.

Table 5. Student's Competency Data

\begin{tabular}{lcccc}
\hline $\begin{array}{c}\text { Critical } \\
\text { Thinking }\end{array}$ & Cog & Afec & Psycho & Ave \\
\hline Low & 69 & 69 & 77 & 71.7 \\
High & 80 & 84 & 81 & 81.7 \\
Average & 74.5 & 76.5 & 79 & 76.7 \\
\hline
\end{tabular}

Table 5 shows student competency data in the low and high critical thinking categories of students. Competencies studied are cognitive, affective, and psychomotor. Students who have high levels of critical thinking have a tendency to achieve all three aspects of competence better than students who have low levels of critical thinking.

\section{Prerequisite Test Results}

The prerequisite test is a test needed before doing the hypothesis test. The prerequisite tests include normality test and homogeneity test. Each of the results of the analysis requirements test is presented as follows:

\section{Normality Test}

The normality test means the data analyzed have truly come from a normally distributed population. The normality test used in this study was the Kolmogorov-Smirnov sta- 
tistics. As a prerequisite, the data that needed to be tested were data in the low and high critical thinking groups. The data distribution rules were declared normal if the sig value > 0.05 . The results of the analysis using the Kolmogorov-Smirnov test, as presented in Table 6.

Table 6. Data of Normality Test Result

\begin{tabular}{ccc}
\hline \multirow{2}{*}{ Group } & \multicolumn{2}{c}{ Kolmogorov-Smirnov } \\
\cline { 2 - 3 } & $\mathbf{F}$ & Significance \\
\hline Low Critical Thinking & 0.180 & 0.128 \\
High Critical Thinking & 0.085 & 0.200 \\
\hline
\end{tabular}

Based on the results of KolmogorovSmirnov test analysis on the low critical thinking group, a significance level of $0.128>$ $\alpha=0.05$ is obtained. In high critical thinking, the group obtained a significance level of $0.200>\alpha=0.05$. From these values, it can be concluded that the data were normally distributed.

\section{Homogeneity Test}

The homogeneity test is a prerequisite test that aims to find out whether the data comes from homogeneous populates or not. The homogeneity test in this study was carried out by the Levene's test method from the average value of the three competencies and critical thinking data. The data distribution rules are declared normal if the sig value $>0.05$. The results of the analysis using Levene's Test are presented in Table 7.

Table 7. Data of Homogenity Test Result

\begin{tabular}{cccc}
\hline \multirow{2}{*}{ Data } & \multicolumn{3}{c}{ Levene's Test } \\
\cline { 2 - 4 } & df 1 & df2 & Significance \\
\hline Critical Thinking & 1 & 68 & 0.711 \\
\hline
\end{tabular}

Based on the results of Levene's Test analysis on critical thinking, data variables obtained a significance level of $0.711>\alpha=$ 0.05 . From these values, it can be concluded that the data are homogeneous or have the same variance.

\section{Hypothesis Test Results}

Based on Table 8, the results of Anava test calculations using SPSS, the significance value of competency is 0.067 , which is bigger than the significance level $\alpha=0.05$. Thus, the conclusion is that $\mathrm{HO}$ is accepted. It means that there are no significant differences in the effect of competency of the student. The significance value of critical thinking is 0.000 , which is smaller than the significance level of $\alpha=0.05$. Therefore, the conclusion is that $\mathrm{H} 0$ is rejected, and H1 is accepted. It means that there are significant differences in the effect of critical thinking skills. The significance value of competency of critical thinking is 0.026 , which is smaller than the significance level $\alpha=0.05$. Thus, the conclusion is that $\mathrm{H} 0$ is rejected, and $\mathrm{H} 1$ is accepted. It means that there is significant interaction in the effect of critical thinking skills on student competencies.

It can be seen from the average that students who have a high level of critical thinking have a better average of competency than those with a low level of critical thinking; thus, this result supports the hypothesis in this study that there are differences in the effect of the level of critical thinking on the value of student competency.

Based on the average value of cognitive competence, the high critical thinking group is superior to the low critical thinking group. The aforementioned research results are in line with research by DePorter et al. (2007), which states that students who have good critical thinking skills will more easily develop their academic knowledge since critical thinking is an important part of education to be able to solve problems and find the solution. Critical thinking is a cognitive process for gaining knowledge because critical thinking is a high-level thinking activity. High-level critical thinking requires the ability to analyze and evaluate, identify questions, make logical conclusions, and understand the implications of arguments (Facione \& Facione, 1994). Students with high critical thinking skills can be indicated to have better cognitive competence compared to groups with low critical thinking skills.

This study also proves that students who have critical thinking skills have a significant effect on students' affective competence. It can be seen from the average value of learning competence in the affective domain. Students who have high critical thinking levels get an average value of 84.29 , while those who have low critical thinking levels get an average value of 69.01. A research conducted by Florea and Hurjui (2015) in the affective domain of critical thinking encourages stu- 
dents to be actively involved in the learning process, to practice cooperation with groups, and to appreciate opinions (Florea \& Hurjui, 2015 , p. 570). Supported by the activeness, cooperation, and the attitude of respect, then the affective competence of students becomes better. It can be concluded that students who have a high level of critical thinking have affective competence in preparing financial statements better than students who have a low level of critical thinking.

In the indicators of psychomotor or skills, students with high and low critical thinking levels have different average; that is, the value of students who think critically high is superior to students who think critically low. It is supported by the fourth and fifth critical thinking indicators from Ennis (1993), which are providing further explanation and setting strategies and tactics. Giving further explanation is included in the psychomotor domain, namely communication skills. Managing strategies and tactics also include the realm of design skills. Therefore, we need critical thinking skills to achieve better psychomotor competencies. Carson (2007) states that although students know a concept, not necessarily students can know how to apply it or use it. There are still many students who find it difficult to apply the knowledge and concepts they know to solve problems. It indicates that students must practice a lot to apply their knowledge to the skills they have. Critical thinking is considered as one of the compulsory abilities needed in the 21 st century (Trilling \& Fadel, 2009, p. 7). It is considered as an ability that needs to be improved in one's life to be more creative and skilled in problem-solving (Ornstein \& Hunkins, 2004, pp. 119-120). In everyday life, critical thinking is used for decision making, forming opinions based on reason, and defending ideas to be accepted (Bassham, Irwin, Nardone, \& Wallace, 2011, p. 1). Where it is part of the psychomotor domain; hence, it can be said that high critical thinking skills significantly influence student's psychomotor competence.

\section{CONCLUSION}

Based on the results of data analysis and discussion of the results of research that had been conducted, it is concluded that students who had high levels of critical thinking, had the higher achievement of student learning competence than those with low critical thinking abilities. The referred student competencies were cognitive, affective, and psychomotor, as the basic competencies needed for preparing financial statements. Thus, teachers need to pay attention to students' critical thinking skills in accounting learning because critical thinking skills in the 21st century are highly needed in problem-solving and decision making in daily life. In subsequent studies, it is best to pay attention to aspects of different levels of education and the field of education.

\section{ACKNOWLEDGMENTS}

The authors express special gratitude to the Directorate of Research and Development of the Ministry of Research Technology and Higher Education of Indonesia, which funded this research.

\section{REFERENCES}

Abimanyu, S. (2008). Strategi pembelajaran. Jakarta: Direktorat Jenderal Pendidikan Tinggi, Departemen Pendidikan Nasional.

Arikunto, S. (2009). Dasar-dasar evaluasi pendidikan (Revised ed). Jakarta: Bumi Aksara.

Baharuddin, E., \& Wahyuni, N. (2007). Teori belajar dan pembelajaran. Yogyakarta: Ar-Ruzz Media Group.

Bassham, G., Irwin, W., Nardone, H., \& Wallace, J. M. (2011). Critical thinking: A student's introduction. New York, NY: McGraw Hill.

Bloom, B. S. (1956). Taxonomy of educational objectives: The classification of educational goals, handbook I cognitive domain. New York, NY: Longmans, Green and Co.

Browne, M. N., \& Keeley, S. M. (2009). Asking the right questions: A guide to critical thinking. Singapore: Pearson/ Prentice Hall.

Bruner, J. S. (1966). Toward a theory of instruction. Cambridge, MA: Harvad University. 
Budiningsih, A. (2005). Belajar dan pembelajaran. Jakarta: Rineka Cipta.

Budiyono, B. (2015). Statistika untuk penelitian. Surakarta: UNS Press.

Carson, J. (2007). A problem with problem solving: Teaching thinking without teaching knowledge. The Mathematics Educator, 17(2), 7-14.

Chukwuyenum, A. N. (2013). Impact of critical thinking on performance in mathematics among senior secondary school students in Lagos State. IOSR Journal of Research \& Method in Education, 3(5), 18-25. Retrieved from http://www.iosrjournals.org/iosr-jrme/ papers/Vol-3 Issue-5/D0351825.pdf

DePorter, B., Reardon, M., \& Singer-Nourie, S. (2007). Quantum teaching: Mempraktikkan quantum learning di ruang-ruang kelas. (A. Nilandari, Trans.). Bandung: Kaifa.

Dewey, J. (1910). How we think. Lexington, KY: D.C. Heath. https://doi.org/ 10.1037/10903-000

Duron, R., Limbach, B., \& Waugh, W. (2006). Critical thinking framework for any discipline. International Journal of Teaching and Learning in Higher Education, 17(2), 160-166. Retrieved from http://www.isetl.org/ijtlhe/pdf/IJT LHE55.pdf

Ennis, R. H. (1993). Critical thinking. Upper Saddle River, NJ: Prentice Hall.

Errington, A., \& Bubna-Litic, D. (2015). Management by textbook: The role of textbooks in developing critical thinking. Journal of Management Education, 39(6), 774-800. https://doi. org/10.1177/1052562915594839

Facione, P. A., \& Facione, N. C. (1994). Holistic critical thinking scoring rubric. Millbrae, CA: The California Academic Press.

Fisher, A. (2009). Critical thinking: An introduction. London: Cambridge University Press.

Florea, N. M., \& Hurjui, E. (2015). Critical thinking in elementary school children. Procedia - Social and Behavioral
Sciences, 180, 565-572. https://doi.org/ 10.1016/j.sbspro.2015.02.161

Glaser, R., \& Resnick, L. (2001). National research center on student learning. Washington, DC: Office of Educational Research and Improvement.

Ikatan Akuntan Indonesia. (2015). Pernyataan standar akuntansi keuangan. Jakarta: Ikatan Akuntan Indonesia.

Jenkins, E. K. (1998). The significant role of critical thinking in predicting auditing students' performance. Journal of Education for Business, 73(5), 274279. https://doi.org/10.1080/088323298 09601644

Karfi, H. (2002). Model-model pembelajaran. Bandung: Bina Media Informasi.

Krulik, S., \& Rudnick, J. A. (1999). Innovative tasks to improve critical and creative thinking skills. In L. V. Stiff \& F. R. Curcio (Eds.), Developing mathematical reasoning in grades $K-12$ (pp. 138-145). Reston, VA: The National Council of Teachers of Mathematics.

McCarthy, M. C. (2004). Critical thinking disposition, belief perspective and academic performance: Examining relationship. Doctoral thesis. Auburn University, Auburn, AL.

Ornstein, A. C., \& Hunkins, F. P. (2004). Curriculum: Foundations, principles and issues. Boston, MA: Pearson.

Paul, R., \& Elder, L. (2001). The miniature guide to critical thinking: Concepts and tools. Dillon Beach, CA: The Foundation for Critical Thinking.

Piaget, J. (1988). Antara tindakan dan pikiran. (A. Cremers, Ed.). Jakarta: PT Gramedia.

Regulation of the Minister of Education and Culture No. 70 of 2013 concerning the Basic Framework and Structure of Curriculum for Vocational High School/Vocational Madrasah Aliyah (2013). Republic of Indonesia.

Riduwan, R. (2010). Skala pengukuran variabel-variabel penelitian. Bandung: Alfabeta. 
Sanjaya, W. (2012). Strategi pembelajaran berorientasi standar proses pendidikan. Jakarta: Kencana Prenada Media Group.

Slavin, R. E. (2000). Educational psychology: Theory and practice (6th ed.). Boston, MA: Allyn and Bacon.

Smith, G. F. (2014). Assessing business student thinking skills. Journal of Management Education, 38(3), 384411. https://doi.org/10.1177/105256291 3489028

Snyder, L. G., \& Snyder, M. J. (2008). Teaching critical thinking and problem solving skills. Delta Pi Epsilon Journal, 50(2), 90-99.

Springer, C. W., \& Borthick, A. F. (2004). Business simulation to stage critical thinking in introductory accounting: Rationale, design, and implementation. Issues in Accounting Education, 19(3), 277-303. https://doi.org/10.2308/iace. 2004.19.3.277

Sukmadinata, N. S. (2009). Metode penelitian pendidikan. Bandung: Remaja Rosdakarya.

Suprihatiningrum, J. (2013). Strategi pembelajaran: Teori dan aplikasi. Yogyakarta: AR-Ruzz Media.

Sutiah, S. (2003). Buku ajar teori belajar dan pembelajaran. Malang: UIN Press.
Thobroni, M., \& Mustofa, A. (2011). Belajar dan pembelajaran pengembangan wacana dan praktik pembelajaran dalam pembangunan nasional. Yogyakarta: Ar-Ruzz Media.

Trilling, B., \& Fadel, C. (2009). 21st Century skills: Learning for life in our times. San Francisco, CA: John Wiley \& Sons.

von Glasersfeld, E. (2007). Learning as a constructive activity. London: Lawrence Erlbaum Associates.

Vygotsky, L. S., \& Cole, M. (1978). Mind in society: Development of higher psychological processes. Cambridge, MA: Harvard University Press.

Zhou, Q., Huang, Q., \& Tian, H. (2013). Developing students' critical thinking skills by task-based learning in chemistry experiment teaching. Creative Education, 04(12), 40-45. https://doi.org/10.4236/ce.2013.412A10 06

ŽivkoviL, S. (2016). A model of critical thinking as an important attribute for success in the 21st century. Procedia Social and Behavioral Sciences, 232, 102-108. https://doi.org/10.1016/j.sbspr o.2016.10.034 